\title{
Time and the Prison Experience ${ }^{[1]}$
}

\author{
by Azrini Wahidin \\ University of Central England in Birmingham
}

Sociological Research Online, Volume 11, Issue 1,

< http://uww. socresonline.org.uk/11/1/wahidin.html>

doi:10.5153/sro. 1245

Received: 28 Sep 2005 Accepted: 17 Mar 2006 Published: 31 Mar 2006

\begin{abstract}
Throughout the literature on time there has been an omission of the qualitative dimension of time in relation to the experience of time in different locales. This paper will explore the nature and role of time-use in prison. Based on intensive fieldwork in 8 male and female prison establishments, this article will explore the experiences of women and men aged 50 years and above, serving a custodial sentence and their relationship with time. The data draws from 90 semi-structured interviews. The aim of this paper is firstly to landscape time use in prison. Secondly, to show how time in prison is negotiated by the prisoners and finally, examine how outside time becomes more real as the transition from a closed to an open prison becomes more imminent.
\end{abstract}

\section{Keywords: Older Offenders, Identity, Time, Prisons}

\section{Introduction}

'Time held me green and dying

Though I sang in my chains like the sea'.

(Dylan Thomas: 1946)

1.1 Time is commonly represented by spatial metaphors. Time is as invisible, untouchable, inaudible as the idea of God, and as indissolubly part of everything. Only the metaphors which are time's language allow us to think otherwise. Our everyday communications are littered with references to time: we speak of clock time and winter time, good times and bad times, of the right time, of a time that flies and a time that takes its toll. Our experience of time is something that is always passing, moving or flowing. We live in, and by, and are caught in time and it is thus not surprising that 'time' is one of the most frequently used nouns in the English language. We are all socially bound to and experience time on various levels from the cyclical, the diurnal and 'when the linear so much overshadows the cyclical, than by hiding the vital, iterative part of its own constitution the social structure becomes that much more difficult to comprehend (Young 1998: 5). Time is not only outside us, it is also inside us, in the form of our internal clocks and their consequences. Our own subjective awareness of time is informed by age, historicity, location, time and space ordering. Our thinking about and our use of time move freely between all these senses yet we know very little about time in all its guises.

1.2 The purpose of this paper is to provide some reflections on time in relation to imprisonment. These arise from a large scale qualitative study on the experiences of older male and female offenders in prison in England and Wales. This article will explore how prisoners negotiate and experience time by focusing on their accounts, since prisoners are valuable sources of knowledge about their prison experience. This paper draws on research arising from work on the experiences of older male and female offenders serving a period of time in prison. Some of the participants have grown old in prison, some have served previous prison sentences and others have been sentenced to a term of imprisonment in later life. This paper draws upon themes developed from extensive research on older offenders in prison.

\section{Methods}

2.1 The prisons ranged from a maximum-secure prison to an open prison, reflecting the various types of prison establishments and criminal offences found in the penal system in England and Wales. The prisons involved in the study were: HMP Durham H Wing, Askham Grange, Styal, Drake Hall Prison, Kingston, 
Norwich, Wymott and Frankland. The studies were based on in-depth semi-structured interviews with prisoners and the age of the participants ranged from $50-85$ years of age. Names and identities have been changed to pseudonyms for purposes of anonymity. The sample consisted of the following categories of 'prisoner':

- The first-time offender currently serving a term of imprisonment.

- The offender who has had previous convictions but not served a prison sentence before.

- The offender who has previously served a custodial term after conviction.

- Prisoners serving a life sentence who have simply grown old in prison.

- Long term prisoners.

2.2 In the course of this work, I spent extended periods in each of the prisons. This meant being there when the prisoners were being un-locked, doing the night shift and being there at weekends. One also sees different things and gets different opportunities to talk at night and at the weekends then during the day. All the four male prisons had either separate wings or units for older prisoners except for the women's prison, where no tailored facilities where available for the older female offender. In total, I conducted over 90 in-depth interviews, ranging from one to four hours, with prisoners aged 50 to 85 years. The interviews were taperecorded and transcribed and a thematic content analysis of the verbatim transcripts was carried out. In my work I was concerned with the experiences of imprisonment for older prisoners. I looked at facilities, regime through to questions around identity, death and dying and in my interviews with prison personnel I examined the issues and challenges they faced in managing the needs of older offenders. Although I interviewed staff from disciplinary through to medical staff and governors, in this paper I will focus on a small yet representative selection of responses to the question about time and the way prisoners experienced time in prison.

\section{Deconstructing Time}

3.1 We are surrounded by pictures of time. The iconography of time has been appropriated to a male persona, changing over time from the Destroyer associated with death and destruction, or the Reaper equipped with the sickle/scythe, to that of the omnipotent, benevolent patriarch, Father Truth and Old Father Time (Davis, 1990). Despite changes in iconography, time never changes gender and this idea of gendered time, I would argue, is under-theorised in sociology. It is noteworthy, that in Greek mythology two distinct, albeit related aspects of time, are represented by the male god Chronos, god of chronology, successive time, and his sister Karios, god(dess) of cyclical time as observed in the changing of seasons and the reproductive cycle. Interestingly, it is the former which survives in contemporary European languages, and which arguably predominates in a culture structured by consumer capitalism. This is not to say that there is something 'essentially masculine' and 'feminine' about these two aspects of time, nor that the structuring of time-consciousness under capitalism can in any simple sense be explained as residing in its 'patriarchal' character. As we shall see, the experience of imprisonment thrusts elder offenders into a temporal order in which time takes on the aspect of a quantifiable commodity to be lost, gained, saved, wasted or ingeniously endured.

\section{The Social Construction of Linear Time}

4.1 It has been argued that the development of the concept of time in sociological theory was inspired and directed by what is generally termed the French tradition, in the writings of Durkheim. In The Elementary Forms of the Religious Life (1961), Durkheim illustrates how the ordering of time is a product of the collective consciousness, a 'rhythm of collective life dominat[ing] and encompass[ing] all particular durations'(2001: 69). For Durkheim, then, time is an abstract, objectively given concept derived from social life interlocking into a plethora of temporal activities.

4.2 In the course of the exploration of the prison timescape it has become clear that before time-discipline, time revolved around the rhythms of the seasons and daily life, and the present timescape which is mechanised and serialised into the 'past', 'present', and the 'future'. Rabinbach (1992), argues that time in its modern form, as linear, that is to say, experienced as an ordered, sequential development, which travels in one direction, more often than not is perceived as a movement from the past to the present and then on towards the future. The point here is that the experience of time is structured by the knowledge of our mortality which imparts an urgency to our use of time. Thus the essence of time-punishment, is time which cannot be recaptured

\section{The History of Time}

5.1 Time became a valuable resource tied to work, capital and gain. It became an economic variable like labour, capital and machinery, a resource that was measured in lengths and handled economically. The contemporary approach to time clearly denotes a historical move away from working in time towards 
working with time to a position where we work for time. Marx comments that 'man is nothing; he is, at most, the carcass of time (Marx and Engels 1976: 127).

5.2 During the industrial revolution there was a growing workers' consciousness of labour in which 'time' became assigned a specific value intruding upon identities, disciplining the body into regimes and sequences of activity governed by the time-table (Foucault, 1979) and ritually ordered time (see Medlicott 1999). It is within this development of industrialisation that time became a valued commodity.

5.3 Through the seminal work of Marx and Engels (1976); Postone, (1978; 1996) and Thompson (1967), one can trace how labour time became a social necessity - constituting, mediating and conditioning identity (Urry, 1991; Giddens 1981, 1991; Nyland, 1990). The development of modern, capitalist society in Western Europe gave rise to the dominant conceptions of time. Adam (1990: 25) argues that this change, in fact, suggests that rather than time being money, money became time. As the new time discipline was imposed, workers began to fight, not against time, but about it. As the currency of time gained meaning:

'The first generation of factory workers were taught by their masters the importance of time; the second generation formed their short time committees in the ten-hour movement; the third generation struck for overtime or time and a half. They had accepted the categories of their employers and learned to fight back within them. They had learned their lesson, that time is money only too well'(ibid).

Time becomes, the most direct expression of class conflict in the capitalist economy. Thompson puts it thus:

'This measurement embodies a simple relationship. Those who are employed experience a distinction between their employer's time and their 'own' time. And the employer must use the time of his labour and see it is not wasted: not the task but the value of the time is dominant. Time is now currency: it is not passed but spent (Thompson, 1967:21, emphasis in original).

5.4 The clock, attained significant value in society. It dictates our movements and inhibits our actions. The clock turns time from a process of nature into a commodity that can be measured, bought and sold. The possession of time varies according to differences in status, power, money and freedom: 'The wealthy can buy the labour, service and skills of others at a time, while agents of the state and persons in positions of authority have the right to time-structure the lives of those under their control' (Adam 1990:114). This paper will demonstrate that in the case of prisoners, it is only if one has very little time, that time gains a greater value and the value of time is dependent on whether the individual has control over time. Time is more valuable when the time available for a certain activity is not as great as the time desired for it. Thus, in terms of prison time, time is not valuable because the prisoners are not in a position to 'spend' it in a manner of their own choosing and in a manner that has value to them. However, the time 'lost' to them is of great value, albeit in a negative sense, because it represents the things they would be doing if the time was theirs to control and 'spend' at will. One therefore needs to take account of quantity, ownership and control of time. Time in prison is problematic. In many cases having a lot of time is of little value to people who have no time of their own such as prisoners in a total institution (Goffman, 1961). Time in prison is no longer a resource to be used, spent or saved but rather an object to be managed in an undifferentiated landscape which has to be marked out or traversed by time frames that connect prisoners with the outside world (Sapsford, 1983). Cohen and Taylor $(1972,1978)$ make a similar point in that 'unlimited time does not have the same subjective appeal for the prisoner as for the hippie drug user' (1972:53).

\section{Undoing Time in Prison}

6.1 In both Psychological Survival (Cohen and Taylor, 1972) and Escape Attempts (Cohen and Taylor, 1978) deal with the problem of doing time. Academic writings and personal narratives about the experience of imprisonment use time as an organising metaphor, for example, Dead Time (Rives, 1989), Doing Time (Matthews 1999), Undoing Time (Evans et al 2000) or Out of Time (McKeown, 2001). Prisoners unlike time users on the outside focus on how to manage time in prison by learning: to 'serve time', to differentiate between 'hard time', and 'easy time', to 'kill time' and try to ultimately survive 'dead time'. They have a dual sense of time passing and standing still. A salient theme running throughout the accounts of the prisoners is that prison time is ultimately about survival.

6.2 The passing of time for the prisoner brings new risks both in prison and once released as they find themselves negotiating a different time order of free society to one which they have left. In its myriad of forms, the capillaries of time in prison does offer and govern possible 'freedoms, representing the 'past', 'present', the 'now' and possible futures. Time in prison, is not only a measurable, tradeable commodity: it is a form of 'currency' that can be also used in prison as a technique of further punishment when days can 
be gained and added to the length of sentence. This time-discipline is enacted through the compulsory time-tabling of a prisoner's location which on the one hand is used to structure the operational needs of the prison, yet on the other can be used as a form of disciplining anyone who is out of sync with prison time. The artificial, abstract construction of penal time inscribes, governs and penetrates into the intimate bodily functions; the biological functions of sleeping, waking and using the toilet become regimented by the prison order of time. This use of time in prison illustrates the multiplicity of 'time' and techniques used in governing the inmate but also provides possibilities for using time in order to survive and negotiate the prison time machine. In as much as prison is an oppressive institution, the positivity of power creates prison as a site of resistance (albeit within externally determined boundaries). Moreover, in this particular timescape, elders show a facility in 'knowing their way around' time, acquiring knowledge about the role time plays in prison. Thus, the voices of the elders illustrate that prison time, although regulated, does assist them in manoeuvering and negotiating the prison performance of the do[ing] of time in prison. Cath manages her time by:

Cath: 'Um, for me it is partly how to avoid being in the cafeteria longer than possible. You've got to eat in order to survive. So how much can you buy from the canteen once a week in the form of Ryvita and things. So after you've trekked in the dining room you can just leave and be by yourself - just listen to the radio or read. Rather than sit like a lot of cattle waiting to be fed. I find it a very unpleasant part of the day. I try to avoid it. So I occupy myself in planning what I am going to buy. So that I don't have to sit in that place more hours than is absolutely necessary. That gives me a sense of autonomy. So that's a time strategy - yes.'

6.3 The extract below explores the coterminous nature of time in relation to the new order of time i.e. prison time; remand time, sentenced time (psychological time), actual sentence time and the doing-of-prison-time, (physical time). In this extract Wan-Nita eloquently discusses how within this island of prison time (i.e. prison structural time) she becomes lost within seas of timelessness (subjective prison time), separated but aware of time passing and time changing on the outside:

Wan-Nita: 'My life on the outside has already gone because from the very first day when you come into jail: you live in a make believe world. For that year, you think you're going home. You know you've got a life sentence but you don't accept it. You think a miracle is going to happen, and each day your life slips away from you a little bit and then one day you wake up in the morning and it's all gone and that's the worse day of all, when everything before has gone.

It was like a diary effect, I was writing about present day and past and it was all mingled in together, it sort of made you cry and laugh at the same time, and that's what happened to me along that way. It all just slipped away. You can't keep hold of time. You can't hold it . It's like my Clare, my baby, who's not a baby anymore. She's a young lady. You can't hold on to that life out there.' (emphasis in original)

6.4 This testimonial demonstrates the initial denial and the unacceptance of prison time as she makes the transition from the free world to the closed world of the prison. The unifying theme is time and the irrevocable loss of not being able to watch her daughter grow. When she came to prison her daughter was only a young child and now she has grown up to become a 'young lady'. For her, the grasp on time has dissipated making it harder to hold on to the world she left behind. Time passes and stands still as the prisoners become temporally and spatially isolated from wider society. Their normal patterns of life are both materially and ideologically severed. This time of incarceration, time standing still yet passing away, permeates the self and through the severance of life threads to the outside world, creates a new temporal order.

6.5 Time becomes part of their lives which elders revolve in and around, in which they are captives too check (prison colloquialism for when prisoners are called to sign a check list), visits, cateen etc. Julie catches herself, falling into a sequence of prison time routines. Although actively resisting the synchronised movements of disciplinary time, many of the elders recognised that they were slipping into the rhythms of prison time. Julie recounts how she tries to control aspect of prison time:

Julie: 'Um.... I still try to retain thoughts about outside. I mean obviously, um I think you have to work hard at not becoming institutionalised. Because you see people being institutionalised. And sometimes you are finding yourself. I mean sometimes you go for a shower at the same time everyday, because you know you've only got so much time left. And sometimes I'll say to myself, 'I'm not going for a shower tonight'. Just because I know I always go at such a time and sometimes it just stares you in the face. I think you fill your flask at a certain time because it is ten minutes before lock in. And I think, 'Oh, no' and you know it's a battle. It's a battle not to become institutionalised because everything is 
regimented.'

6.6 Every time-strategy or technique used, no matter how individually determined, bears within it the stamp of social time, for nobody can free themselves of the temporal patterns of the outside and in prison which bind her to others (Cohen and Taylor, 1972, Urry, 2000). Caroline shows the significance of clock-time as she watches the clock in prison as opposed to not even looking at it on the outside. Her words make us see time as something that means everything: it is how the minutes, hours, days and years are structured.

Caroline: 'Time, in prison is quite different because you're watching the clock whereas you don't necessarily look at the clock on the outside. I mean the clock was there and you might glance at it, but here clock-time means everything (emphasis in original)

6.7 As we can see from the testimonial below the removal from the outside world is only one type of punishment. It is the severance from all that is familiar, from the sight and smells of everyday life that suspends the temporal understanding of the free world. As the link with outside time becomes more tenuous, prisoners face sensory and temporal deprivations. In terms of 'the outside', the prison structuring of time usurps the time ordering of what was known and familiar. Molly poignantly describes the severance of outside life threads, as not seeing 'a whole of anything', as the space of the prison cut her 'off completely from the outside world':

Molly: 'We were in this old castle, the windows are way up at the top, and so you never saw out unless you were on the top floor. You never saw a whole sparrow. So you never saw a whole tree or a whole sky. You didn't see a whole anything, it was like a patchwork quilt. It shut you off completely from the outside world.' (emphasis in original)

6.8 In doing time, time can be harnessed, disciplined, forfeited (remission days lost), gained (added days), negotiated, managed, survived and feared. Throughout the extracts, prison time becomes the enemy, insidiously penetrating all aspects of social life. The prison day is essentially empty and one day closely resembles the other. Similar, to many personal accounts, Molly describes the passing of time as a form of cryogenic suspension:

Molly: 'Time has stood still whilst I have been in prison. Time has stood still in that everything goes on and on in the same repetitive way. It is as if the nineteen years could have all been fitted in one year.' (my emphasis).

Another explains, that phenomenon of time discipline is that, 'Every single day is the same. It drives you mad!' It is the routinisation, the severance with the outside world that leads to:

Paulette: 'The boredom and isolation, I think because every day is the same. It is just dreadful. Every single day is the same. It drives you mad! I don't know how you come out and you're sane. Because every single day is just actually the same as the day before. Your meals are the same time. Everything. Oh it's horrible. I'm telling you - it really is. I mean you've got to do time because you've committed a crime. But the fact that it goes on and on and on and on - There is just no end to it. You are thinking to yourself my God when is this going to end? So it does wear you down.' (emphasis in original).

Time as discussed above has been constructed to discipline and bring about the social death of the outside self through temporal and sensory deprivation (Cohen and Taylor, 1972, 1992; Christie, 1981). Olivia, a first time offender serving an eight year sentence, reiterates how time in prison becomes a variant of punishment:

Olivia: 'Some days I just climb the walls. I have a lot of sleepless nights as well - it seems never-ending. It seems as though it is never going to happen when you are going to walk out of that gate for good. And it is just damn hard to cope with some days. It is very hard and when you are up against it all the time you wonder how much more you can take.'

The disciplinary gaze allows the trajectory of time to be systematically welded into types/forms of punishment. For example Anita, who is at the beginning of her sentence, has experienced how punishment on an informal level is distributed by time:

Anita: 'You see the way they can get back at you if they take a dislike to you is they [the prison officers] will go over for your visits late. So that cuts the time down for you. What she [the prison office] used to do is make me stay on the wing and take the others through and say my visitors wasn't there.'

6.9 Each woman and man found ways of differentiating and dividing time. In the doing of time, they 
manipulate, 'consciously toy, bend, and mould' time in order to survive (Scarce 2002: 306). Some interact with time by making time digestible, ticking months off, weeks off and even days off, placing time around visits or parole dates and others try and fit everything into one day.

Flo: 'Oh yes, yes, I was crossing them off and then I was leaving them to the end of the month. I've got my calendar and l've marked half of March off. Tonight l'll mark the other page off and turn the page to April and see if it goes any quicker that way by doing it at the end of each month instead of doing it day by day.'

To claim autonomy over prison time, this prisoner places 'everything in a day'. He has reinvented the ordering of time by shortening the day by going to bed at $4.00 \mathrm{pm}$ and waking up at $3.00 \mathrm{am}$. This enables him to have quiet time whilst everyone else is asleep.

Jim: Time... time. If you are doing a long time it is never ending then it does tend to get boring and that is why I find it helps to put everything in a day. I mean I often say and this is the truth, that for me the day isn't long enough and that's the simple reason - I put everything in a day.

6.10 In these circumstances, prisoners have to sustain their lives in some way and look around for ways of marking time (Roy, 1990). Whilst forced to 'mark time' in prison most attempt to make prison time meaningful. Others view their time in prison as 'an interruption of life, not part of it, like a form of cryogenic suspension' (Sapsford, 1983: 96). The dimension of time and its capillary encoding in prison becomes something, which is feared by the prisoners as they see themselves losing their hold on time in prison mentally and physically. They are severed from the outside use of time and live in a world of Dead / Empty time, devoid of 'meaningful' social interaction which allows for:

'Minutes, hours, days [to] slip away with terrifying insubstantiality. Months will pass away like this, and years. Life! The problem of time is everything. Nothing distinguishes one hour from the next. The minutes and hours fall slowly, torturously. Once past, they vanish into near nothingness. The present minute is infinite. But time does not exist' (Serge, 1963: 7) (my emphasis).

\section{‘Catching' time}

6.11 Although time is a basic structuring principle of prison life, the elders found innovative ways of catching time and mediating the time of the real. It is by creating meaningful and symbolic activity that the prisoners found ways of tracing, connecting and maintaining life threads to the outside world and in turn arresting the social death of the outside. Farzana, who is actively fighting against her conviction, describes poignantly how the outside world for her has receded and how desperately she is keeping hold of the real:

Farzana: The longer it goes on the more painful it is to be apart from them. I want my children and my friends to get on with their lives but sometimes, especially when it comes to like Christmas time and things like that, it's as if you are on a thread and that thread is getting finer and finer. Somehow you feel that you are losing contact. As I said I get loads of letters and they say we don't like telling you but we've booked a holiday. I write back and say, please tell me because there is a life outside this prison. You can become cocooned by the prison environment and I don't want that. I want to know. I mean everyday I watch the news. Everyday, I try and get hold of a newspaper because I want to still hold on to what's on out there.' (emphasis in original)

6.12 In order to survive the new order of prison time, they learn to exercise autonomy over time by creating spaces in which they can suspend the outside world but, simultaneously, in an unprecedented fashion 'float' and 'flow' between the prison and the outside world mediated through newspapers, letters and television - or by fantasy. To compensate for the loss of those feelings and activities performed in daily life on the outside, those that survive find innovative ways of catching time. Anita, disciplines time through fantasy by putting herself in another space and time.

Anita: 'You have to try and visualise and remember. Like at nights, when I start saying my prayers, it is as if I go home. I go through my front door and I go round the house and then finally I go up-stairs and into the bedroom and I get into my own bed. Being with the person that you love, you don't forget how that feels. But you forget what it's like to just get up and go and have a bath. Or a shower. To cook a meal. Or just to put the kettle on and make a drink. Instead of having to drink out of a flask. Instead of having a luke-warm drink out of a flask. Just to be able to choose what you eat. Eat when you want to eat and food that you want to eat.' (emphasis in original) 
6.13 The appropriating and the disciplining of time in this socially marooned environment involves a high level of surveillance that conditions and controls the activities in prison. The use of time as a mechanism of surveillance and control is more pervasive in prison and becomes disassociated from the rhythms of time on the outside. Time acquires a different meaning under the carceral gaze, where time is defined and controlled by others. It is something over which they have no control and yet it is something they do negotiate and work within.

6.14 The effects of time in prison penetrate, contaminate and regulate the body through time-tabling and the regimentation of the day. The most distinctive effect comes from the process of 'doing time' which has to be learned; learning to 'do time' is having the ability to suspend the self from the free world (Smith, 1962). In the voices of the prisoners we learn that in order to survive the new order they create transgressive spaces in which they suspend the outside world. In order to survive, they perform an automatic mode of functioning regulated and punctuated by the calls for check, medication and meals. Flo describes this process as being wound up and then left to run down like a robot. One can argue, that this use of the robot metaphor illustrates how the prison system attempts to efface agency in order to create this robotic similarity:

Flo: 'Yes, yes, well you're just like robots. You are just like a wind up robot really. They (the prison officers) just wind you up and they just let you run down at night. It's just that every day is the same. You get up, it's just so boring, so terribly boring. You just like wait for your visits.'

6.15 Time in prison is experienced as time in stasis, stagnant, waiting, yet always in process. For many they found that the passing of time took longer on the inside than on the outside because they were always in a process of just waiting for an answer and waiting for someone to answer their query:

Davina: 'Waiting. You have to wait for everything. You have to wait to put in an application to have clothes brought in for you. You have to wait for an application to go and see the Governor. You always have to wait.' (emphasis in original).

6.16 The passage below illustrates the movement and the medley of time, which is neither coherent nor linear. It is the wakening from the cocooned slumber of the closed world to the world, which lies beyond the gates. Unlike some of the women, Molly found the movement from the closed world to an open prison allowed the experience of time to pari passu because, as she argues, 'there is a hell of a lot to learn out there':

Molly: 'In an open prison, we are really interested because we are going out on home visits' for two days, then three days, then four days, then five days, and it sticks to six days until six months before we leave, it goes up to seven days. So when you are going out all the time and you are having days out - so suddenly there is a hell of a lot to learn out there.' (emphasis in original)

A.W: 'Do you feel that the longer you are in here the more distant you become with what's happening on the outside?'

Molly: 'Yes, the longer I am in. But I am now getting frustrated because I know what the outside world is like. I know from the outside visits. I want to be out all of the time now.' (emphasis in original).

6.17 The closed prisons represent the severance of the outside and an existence in a closed world of marginality but in Molly's case, the movement through to an open prison shows how her life threads begin to look towards what lies beyond the gates. Prison time steals on procrastinating, in contrast to the time on the outside, where we run out of time. Molly recalls her amazement at the technological and monetary changes that have occurred during her twenty years in prison:

Molly: 'Once you have been out - you know what you are going out to at long last, for example the currency has changed. When I came in, it had just changed. I had never seen the twenty pence piece; the new ten pence piece, which is half the size of the other, or the five pence coin. The currency is different. The prices of everything outside are different. I find people less friendly than they used to be - you go out shopping and everyone is rushing around. People now keep very much to themselves, they read their paper, they are on their mobile phones, and it's totally different. I have slowed down here, as there is nothing else to do. Outside everyone is rushing. The time concept is totally different.

6.18 We did the books, handled cheques, cards - you know those funny cards, which l've never seen before - credit cards. I had applied for a Barclay's credit card in 1978 just before I came to prison. I have never seen these plastic things - now everybody is using them, you don't carry money, you just carry them. 
When I went out it was with great excitement. I thought banks had telephones but of course it was where the money came out (She laughs).

Molly: I thought it was a telephone, 'where do you speak', I said.

She said: 'Don't be stupid Molly, don't show me up.'

'So tell me, where do you speak?'

'You don't, that's where you get your money out.'

'But the banks are open'. 'It doesn't matter, you don't have to go into banks any more, you

just press these things.'

'I thought it was a telephone.'

'I get excited when I go out now, so many new things to find out about, everything has

changed so much.' (emphasis in original).

6.19 The voices of the prisoners illustrate that there is a multiplicity of time and time use in prison. These detailed accounts emphasise the nature of time in prison as a form of discipline which can be resisted, negotiated or internalised. Although time in prison is punctuated by roll calls, check, visits, meals, and association time, prison time never changes as one moves from one category of prison to another.

\section{Conclusion}

'There are swift hours and very long seconds. Past time is void. There is no chronology of events to mark it; external duration no longer exists' (Serge, 1977: 35).

7.1 It is through our unbending support in a beginning and an end that allows outside time for elders in prison to feel that time once released is a scarce resource to be savoured, lived and experienced. The stories of the prisoners show how they are exposed to a type of punishment which is underpinned by timediscipline. They are caught within the movement and motions of time and space, both within the time of the real on the outside and in terms of prison time. This is the in-between space of carceral time within which prisoners live and which they negotiate.

7.2 Time in prison is mediated by the boundaries of the institution, imposed from above by a system of explicit formal rules, practices and procedures. The use of 'time as imposed' seeks to eliminate 'choice' and in turn instils dependency. This in turn seeks to deny the society of captives (Sykes, 1958) the capacity to create meaningful and symbolic relations with prison-time and external time in the free society.

7.3 Time in prison is something, which is lived through but not in the real sense lived. Of course, days come and go, but they do not pass as they do on the outside. It is not just the division of time, which concerns those incarcerated, but the rate at which time passes. However, if any one has watched a kettle boil, in the same way if a letter or a visitor fails to arrive, the experience of waiting gives monotony the upper hand, joined by its inevitable, constant companion, fatigue. We all in one way or another have become 'clock-watchers', servants to the concept of time, which we have made, held in fear, like Frankenstein by his own monster.

\section{Notes}

${ }^{1}$ I would like to thank the anonymous reviewers for their comments.

\section{References}

ADAM, B. (1990) Time and Social Theory. Cambridge: Polity Press.

CHRISTIE, N. (1981) Limits to Pain. Oxford: Martin Robertson.

COHEN, S. and Taylor, L. (1972) Psychological Survival: The Experience of Long-Term Imprisonment. Harmondsworth: Penguin.

COHEN, S. and Taylor, L. (1978) Escape Attempts: The Theory and Practice of Resistance to Everyday Life. London: Pelican Books.

DAVIS, K (1990), Women, Time and the Weaving of the Strands of Everyday Life. Aldershot: Avebury.

DURKHEIM, E and Mauss, M. (1994) Primitive Classification: The Argument and its Validity. New Jersey: Allen. 
DURKHEIM, E. (2001) The Elementary Forms of Religious Life. Trans by Carol Cosman. Oxford: Oxford University Press.

EVANS, J., Santiago, J.B. and Haney, C.W. (2000) Undoing Time: American Prisoners in Their Own Words. Boston: Northeastern University Press.

GIDDENS, A. (1981) 'Agency, Institution and Time - Space Analysis' in K. Knorr-Cetina and A.V. Cicourel (eds), Advances in Social Theory and Methodology Toward an Integration of Micro and Macro Sociologies Boston Routledge and K.P:161-174.

GIDDENS, A. (1984) The Constitution of Society. Cambridge: Polity.

GIDDENS, A. (1991) 'Structuration Theory: Past, Present and Future', in C Bryant and D. Jary (eds), Giddens' Theory of Structuration . London: Routledge: 201-21.

GOFFMAN, E. (1961) Asylum - Essays on the Social Situation of Mental Patients and Other Inmates. Garden City: N.Y. Doubleday.

GOFFMAN, E. (1990) The Presentation of Self in Everyday Life . London: Penguin.

MATTHEWS, R. (1999) Doing Time: An Introduction to the Sociology of Punishment. Basingstoke: MacMillan.

MCKEOWN, L. (2001) Out of Time: Irish Republican Prisoners, Long Kesh 1972-2000. Belfast: Beyond the Pale, BTP Publications Ltd.

MARX, K. and Engles, F. (1976) Collected Works Volume 5 April 1845 - April 1847. London: Lawrence and Wishart (Capital, Vol, 1, p.129) (translation amended).

MEDLICOTT, D. (1999) 'Surviving in the Time Machine: Suicidal Prisoners and the Pains of Prison Time' in the Journal of Time and Society Vol 8 (2) 211-230

NYLAND, C. (1990) Capitalism and the History of Work Time Thought in J. Hassard (ed) The Sociology of Time. London: Macmillan, pg 131-154.

POSTONE, M (1978) 'Necessity, Labour, And Time A Reinterpretation of The Marxian Critique of Capitalism' in The Journal Social Research: Vol 45:739- 788.

POSTONE, M (1996) Time, Labour, and Social Domination a Reinterpretation of Marx's Critical Theory. Cambridge: Cambridge University Press.

RABINBACH, A (1992) The Human Motor - Energy, Fatigue and the Origins of Modenrity. Berkeley: University of California Press.

RIVES, J. (1989) Dead Time: Poems from Prison. Hamilton, Ontario: Mini Mocho Press.

ROY, D. (1990) 'Time and Job Satisfaction', in J. Hassard (eds), The Sociology of Time, London. Macmillan:155 - 167.

SAPSFORD, R. (1983) Life Sentence Prisoners - Reaction, Response and Change. Milton Keynes: Open University Press.

SCARCE, R. (2002) 'Doing Time as an Act of Survival', Symbolic Interaction, 25, 303-321.

SCRATON, P., Sim, J and Skidmore, P. (1991) Prisons Under Protest. Milton Keynes: Open University Press.

SERGE, V. (1963) Memoirs of a Revolutionary, 1901-1941. London: Oxford University Press.

SERGE, V. (1977) Men in Prison, London. Writers and Readers.

SMITH, A. (1962) Women in Prison - A Study in Penal Methods London: Stevens and Sons.

SYKES, G. (1958) The Society of Captives: A Study of a Maximum Security Prison, Princetown. New Jersey: Princeton University Press.

THOMPSON, E. P. (1967) Time, Work - Discipline and Industrial Capitalism, in Past and Present 38: 51-68. 
URRY, J. (1991) 'Time and Space', in C. Bryant and D. Jarry A. Giddens' (eds), Theory of Structuration. London: Routledge: 160-175.

URRY, J. (2000) Mobile Society, British Journal of Sociology 51(1):185-203.

WHITROW, J.G. (1972) The Nature of Time. Middlesex: Penguin.

YOUNG, M. (1988) The Meteronomic Society. London: Thames and London. 